\title{
HCCS Gene
}

National Cancer Institute

\section{Source}

National Cancer Institute. HCCS Gene. NCI Thesaurus. Code C75501.

This gene may be involved in the electron transport cascade. 